\title{
Article \\ Ebb-and-Flow Subirrigation Improves Seedling Growth and Root Morphology of Tomato by Influencing Root-Softening Enzymes and Transcript Profiling of Related Genes
}

\author{
Kelei Wang ${ }^{1,2}$, Muhammad Moaaz Ali ${ }^{1}$ (D), Keke Pan ${ }^{2}$, Shiwen $\mathrm{Su}^{2}$, Jian $\mathrm{Xu}^{2}$ and Faxing Chen ${ }^{1, *(D)}$ \\ 1 College of Horticulture, Fujian Agriculture and Forestry University, Fuzhou 350002, China; \\ wangkelei@wzvcst.edu.cn (K.W.); muhammadmoaazali@yahoo.com (M.M.A.) \\ 2 Wenzhou Vocational College of Science and Technology, Wenzhou 325014, China; \\ pankeke@wzvcst.edu.cn (K.P.); sushiwen@wzvcst.edu.cn (S.S.); xujian@wzvcst.edu.cn (J.X.) \\ * Correspondence: fxchen@fafu.edu.cn
}

Citation: Wang, K.; Ali, M.M.; Pan,

K.; Su, S.; Xu, J.; Chen, F.

Ebb-and-Flow Subirrigation

Improves Seedling Growth and Root

Morphology of Tomato by

Influencing Root-Softening Enzymes

and Transcript Profiling of Related

Genes. Agronomy 2022, 12, 494.

https://doi.org/10.3390/

agronomy12020494

Academic Editor: Jose

Manuel Gonçalves

Received: 19 January 2022

Accepted: 14 February 2022

Published: 16 February 2022

Publisher's Note: MDPI stays neutral with regard to jurisdictional claims in published maps and institutional affiliations.

Copyright: (c) 2022 by the authors. Licensee MDPI, Basel, Switzerland. This article is an open access article distributed under the terms and conditions of the Creative Commons Attribution (CC BY) license (https:/ / creativecommons.org/licenses/by/ $4.0 /)$.

\begin{abstract}
Ebb-and-flow subirrigation is a promising strategy to increase water use efficiency, avoid waterlogging or drought conditions, and promote the overall growth of vegetable crops. The aim of this study was to evaluate the seedling growth, root morphology, activities of root-softening enzymes, and transcript profiling of those enzyme-related genes in tomato under top sprinkle irrigation and ebb-and-flow subirrigation. The results showed that ebb-and-flow subirrigation could significantly improve stem diameter, root fresh weight, root dry weight, root volume, and root diameter of tomato by $9.42 \%, 45.92 \%, 44.82 \%, 15.61 \%$, and $9.41 \%$, as compared with top sprinkle irrigation, respectively. The ebb-and-flow subirrigation also maintained the root activity and photosynthetic rate of tomato seedlings. The activities of superoxidase dismutase, peroxidase, catalase, glutathione reductase, and ascorbate peroxidase of tomato roots under ebb-and-flow subirrigation were remarkably increased, while the malondialdehyde content was decreased compared with the plants grown under top sprinkle irrigation. Correlation analysis among activities of root-softening enzymes and transcriptomic profiling of their biosynthesis-related genes revealed that 10 genes might be responsible for regulation of studied enzymes. Overall, ebb-and-flow subirrigation could significantly promote the growth of tomato seedlings, so as to maintain high activity and promote the cultivation of high-quality and strong seedlings.
\end{abstract}

Keywords: peroxidase; root activity; photosynthesis; antioxidant enzymes; transcriptome

\section{Introduction}

Tomato (Solanum lycopersicum L.), belonging to the Solanaceae family, is a greenhouse vegetable crop native to Peruvian and Mexican regions [1,2]. It is a rich source of natural antioxidants, including flavonoids, carotenoids (mainly lycopene and $\beta$-carotene), and vitamins A, B, and C [3-6]. Vegetable production in greenhouses demands high fertilizer and water inputs in order to achieve better yield and superior quality produce [7-10]. Common irrigation practices for greenhouse vegetable production include the top sprinkle irrigation system (TSI), which is not considered to be environmentally friendly as large volumes of water and fertilizers are frequently wasted and may runoff/leach, polluting surface and groundwater systems [11-13]. Besides, the seedlings around the hole plate will grow poorly due to water shortage, resulting in inconsistent seedling height [14-16].

The ebb-and-flow irrigation (EFI) system, which is an evolved form of continuous floating system, was originally designed to grow tobacco (Nicotiene tebacum L.) plants to increase field survival and reduce transplant shock and is now being used in China, Japan, USA, and other developing countries to grow a large number of commercial vegetables [17]. It has many advantages such as root moisture optimization, water saving, and fertilizer saving as compared to top sprinkler irrigation [18-20]. Seedling trays are suspended on 
metal wires $\approx 0.20 \mathrm{~m}$ above a concrete floor, and every $2-3$ days the irrigation water is raised to the level of the container, maintained for $15-45 \mathrm{~min}$ and then decreased to its original level or returned to the main reservoir until the next irrigation. In this system, water or nutrient solution is transported to the plant root through the bottom of a cultivation container by the capillary action of the cultivation medium, which can effectively avoid edge or umbrella effects and improve plant uniformity $[17,21,22]$. Some studies in subirrigation, performed mainly with ornamental species, have demonstrated that the concentration of the nutrient solution may be reduced by up to $50 \%$ when compared to nutrient solutions for top sprinkle irrigation, with no detrimental effects on plant growth and quality $[9,23]$. Subirrigation systems improve the uniformity and quality of bell pepper (Capsicum annum L.) and tomato (S. lycopersicum L.) if grown with minimal nutrient and drought stress [24-26].

Different irrigation methods cause differences in root growth [27]. However, prolonged durations of waterlogging and anaerobic respiration ultimately lead to the accumulation of aldehydes, combined with an increase in reactive oxygen species (ROS), thus eventually leading to cell death and plant senescence [28,29]. Hindered gaseous exchange can also lead to the rapid accumulation or degradation of plant hormones and further affect plant waterlogging tolerance [30,31]. When plants are under waterlogging or drought stress, the activities of protective enzymes in plants change dynamically [32,33]. In a recent study, the activities of superoxide dismutase (SOD), peroxidase (POD), catalase (CAT), and other protective enzymes in the roots of sesame seedlings increased at the initial stage of flooding and decreased significantly with the extension of water stress time [34,35].

There are few reports about the mechanism of plant root growth, development, and physiological changes under ebb-and-flow irrigation and top sprinkler irrigation. Therefore, taking tomato as material, this experiment studied the seedling growth and physiology, root morphology, activities of root softening enzymes, and transcript patterns of their metabolism-related genes in tomato under top sprinkle and ebb-and-flow irrigation systems, so as to provide a theoretical basis for the popularization and application of ebb-and-flow irrigation technology.

\section{Materials and Methods}

\subsection{Plant Source, Experimental Design and Irrigation Treatments}

A greenhouse experiment was conducted at experimental farm of Wenzhou Vocational College of Science and Technology, Wenzhou, China $28^{\circ} 05^{\prime} 39.5^{\prime \prime} \mathrm{N} 120^{\circ} 30^{\prime} 55.2^{\prime \prime} \mathrm{E}$ ) from 15 August 2019 to 19 September 2019. Six-month-old seeds of the pure line tomato cultivar 'Ouxiu 201' (round shaped fruit with regular leaves) were obtained from Institute of Vegetable Science, Wenzhou Academy of Agricultural Sciences, Wenzhou, China. The initial germination and seed moisture content before sowing were $84 \%$ and $10.5 \%$, respectively. Tomato seeds were sown in seedlings trays $(540 \mathrm{~mm} \times 280 \mathrm{~mm}$ ) having 50 plugs (each having volume of $55 \mathrm{~mL}$ with upper and lower diameter of 48 and $18 \mathrm{~mm}$, respectively). Seedling trays were purchased from Taizhou Longji Plastics Co., Ltd., Taizhou, China. Seedling plugs were filled with growing media containing peat, vermiculite, and perlite (3:1:1), which were obtained from Hangzhou Lin'an Jindalu Industrial Technology Co., Ltd., Hangzhou, China. The $\mathrm{pH}, \mathrm{EC}$, and organic matter of the growing media were 6.34, $0.87 \mathrm{~ms} \cdot \mathrm{cm}^{-1}$, and $95.4 \%$, respectively. The ebb-and-flow subirrigation system (Patent No.: ZL201520333950.6) used in the experiment was developed by Wenzhou Academy of Agricultural Sciences, Wenzhou, China. It contained a nursery frame, a number of ebband-flow trays horizontally placed on the nursery frame, and a water or nutrient solution circulation device (Figure 1). 


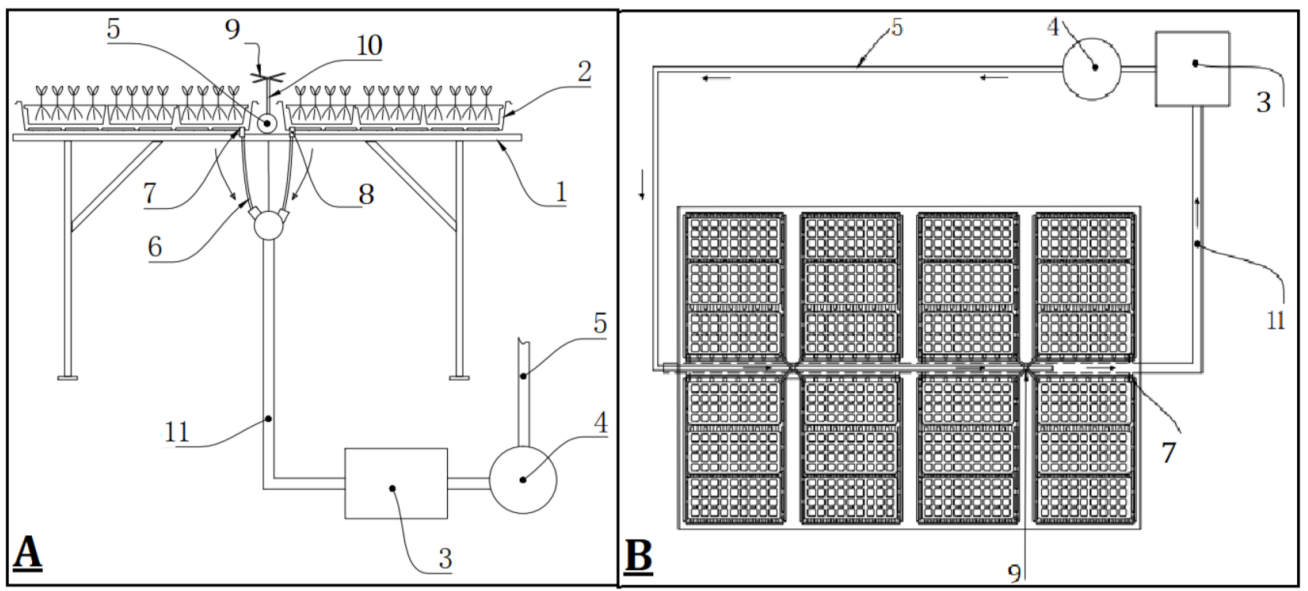

Figure 1. Lateral (A) and top (B) view of ebb-and-flow nursery raising system. 1-nursery frame; 2-ebb-and-flow tray; 3-water reservoir; 4-disinfection equipment; 5-inlet main pipe; 6-drainage branch pipe; 7-drainage hole; 8 -filtering parts; 9 -inlet branch pipe; 10 -five-way connector; 11-drainage main pipe.

Tomato seedling trays were placed on ebb-and-flow irrigation (EFI) seedling raising system [36], as well as on simple beds for top sprinkle irrigation (TSI) water treatment. The top sprinkle irrigation was carried out by manually holding the watering can. There was no fertilizer applied during the experiment. Six seedling trays were used for this experiment, each being considered as a replication of different irrigation treatments, i.e., EFI and TSI. Each irrigation treatment had three repetitions with 50 plants in each repeat. The experiment was designed under a completely randomized design (CRD).

The seedlings receiving both irrigation treatments were placed in the same greenhouse under natural environmental conditions. During the experimental period, maximum and minimum temperatures were $30.85 \sim 37.95{ }^{\circ} \mathrm{C}$ and $21.43 \sim 25.48{ }^{\circ} \mathrm{C}$, respectively. The highest relative humidity was $82.39 \sim 99.65 \%$ and the lowest was $45.11 \sim 71.67 \%$. The maximum and minimum light intensity was $204.26 \sim 1258.53$ and $1.28 \sim 37.26 \mu \mathrm{mol} \cdot \mathrm{m}^{-2} \cdot \mathrm{s}^{-1}$, respectively.

\subsection{Morphological Attributes}

Thirty-five days after sowing (DAS), with the plants at the stage of 6 true leaves, plant height and stem diameter were determined on 10 randomly selected seedlings from each replication of each treatment. On the same date, whole plants were taken out and the fresh weight of each plant was measured using a digital weighing balance (MJ-W176P, Panasonic, Japan). Each plant was then separated into leaves, roots, and stem. The roots of tomato seedlings were washed with water to remove media and other impurities, then dried with paper. The root morphological attributes, i.e., root length, root surface area, root volume, average root diameter, and number of root hairs were analyzed by WinRhizo Pro 2012 root analysis system (STD4800, WinRHIZO, Quebec, QC, Canada). For dry weight determination, individual plant sections were oven-dried at $70{ }^{\circ} \mathrm{C}$ until constant dry mass was attained [7,37]. Root weight ratio and leaf weight ratio were calculated by dividing the dry weight of roots and leaves by the dry weight of the whole plant, respectively [37-39]. Root-to-shoot ratio was calculated by dividing the dry weight of below-ground parts by the dry weight of above-ground parts of the plant $[37,38]$.

\subsection{Physiological Attributes}

At 35 DAS, before the biological harvesting of tomato seedlings, net photosynthetic rate $(P n)$, stomatal conductance $(G s)$, and transpiration rate $(\mathrm{Tr})$ were recorded from the fully expanded leaves from the top of the plant canopy using the Portable Photosynthesis System (LI-6400XT, LI-COR Biosciences, Nebraska, USA). Measurements were made between 6:00 a.m. and 7:00 a.m. The chlorophyll content of the leaves was measured with a 
chlorophyll SPAD meter (CCM-200 plus, Opti-Sciences, Hudson, NH, USA) according to the manufacturer's instructions and presented as SPAD values. Water use efficiency (WUE) was calculated by dividing net photosynthetic rate with transpiration rate $(\mathrm{Pn} / \mathrm{Tr})$ as described earlier [40]. The root activity was measured by the TTC method [41].

\subsection{Enzymes Activity Assay}

At 35 DAS, root samples $(0.5 \mathrm{~g})$ were collected from 10 randomly selected seedlings from each replication of each irrigation treatment and quickly frozen in liquid nitrogen. The $1 \mathrm{~mL}$ of $0.1 \mathrm{M}$ phosphoric acid buffer $(\mathrm{pH}=7)$ was added into frozen root samples, ground, and homogenized in an ice bath. The final volume of $5 \mathrm{~mL}$ was made by adding $0.1 \mathrm{M}$ phosphoric acid buffer $(\mathrm{pH}=7)$, and $2 \mathrm{~mL}$ was taken and centrifuged at 10,000 rpm for $10 \mathrm{~min}$. The supernatant was obtained as the crude extract of enzyme solution [42] and stored at $4{ }^{\circ} \mathrm{C}$ for further analysis.

The activity of superoxidase dismutase (SOD; EC 1.15.1.1) was assayed using a xanthine-xanthine oxidase system [43]. The change in absorbance was read at $560 \mathrm{~nm}$. Peroxidase (POD; EC 1.11.1.7) activity was determined using a previously described method [44]. The change in absorbance was read at $470 \mathrm{~nm}$ for $4 \mathrm{~min}$. Catalase (CAT; EC 1.11.1.6) activity was assayed as described previously [45]. The reaction was initiated with the enzyme extract. The decrease in absorbance (due to decomposition of $\mathrm{H}_{2} \mathrm{O}_{2}$ ) at $240 \mathrm{~nm}$ was recorded for $1 \mathrm{~min}$. Ascorbate peroxidase (APX; EC 1.11.1.11) activity was measured as previously described by Nakano and Asada [46]. The absorbance was measured at $290 \mathrm{~nm}$ for $1 \mathrm{~min}$. The activity of glutathione reductase (GR; EC 1.6.4.2) was measured using the method earlier described by Cakmak et al. [47]. The decrease in absorbance was recorded for $1 \mathrm{~min}$ at $340 \mathrm{~nm}$ due to NADPH oxidation.

Cellulase (C-ase; EC 3.2.1.4) activity was determined by a test kit (A138-1-1, Nanjing Jiancheng Bioengineering Institute, Nanjing, China), while ACC synthase (ACS; EC 4.4.1.14) was determined by an ELISA Kit (JM-09939p2, Jiangsu Jingmei Biotechnology Co., Ltd., Taizhou, China). The malondialdehyde (MDA) content was determined with TBA reaction method [48].

\subsection{RNA Extraction, Illumina Sequencing and Gene Expression}

Total RNA was extracted from tomato roots using an RNase plants mini-Kit (Omega, New York, NY, USA). The nano-spectrophotometer (ND2000, Thermo Scientifc, Waltham, MA, USA) was used to assess the quality and quantity of RNA. Libraries were constructed and sequenced using Illumina HiSeq (Xten's PE150, Novogene, Beijing, China). Reads containing adapters and sequences with more than $10 \%$ unknown nucleotides $(\mathrm{N})$ were first removed from the data set. The filtered clean reads were compared with the genome of S. lycopersicum using TopHat (ver. 2.0.12) [49]. The HTSeq (ver. 0.6.1) was used to count the reads numbers mapped to each gene [50]. Gene expression levels were standardized using the fragments per kilobase million mapped fragments (FPKM). Then, FPKM of each gene was calculated based on the length of the gene and read count mapped to this gene. All analyses consisted of 3 biological and 3 technical replicates. Table S1 contains the gene IDs, FPKM values, and descriptions of all studied genes.

\subsection{Statistical Analysis}

Collected data were subjected to Student's t-test using Microsoft Excel (ver. 2016). Correlation coefficient values were determined with Pearson $(n)$ method using IBM SPSS software (ver. 17.0) and visualized through a heat-map using TBtools software (ver. 0.6655) [51].

\section{Results}

\subsection{Morphological Attributes}

The plant height and stem diameter of tomato seedlings under the influence of ebb-andflow irrigation were $12.36 \%$ and $9.42 \%$ higher than those receiving top sprinkle irrigation, respectively (Figure 2A,B). The fresh and dry weight of tomato roots was also $45.92 \%$ and 
$44.82 \%$ higher with ebb-and-flow irrigation as compared to top sprinkle irrigation, respectively (Figure 2C,D). Under the influence of irrigation treatments, the biomass accumulation percentage in tomato leaves was almost same as in roots, as evidenced by measured fresh and dry weight of tomato leaves. The plants irrigated with ebb-and-flow irrigation exhibited maximum leaf fresh $(4.45 \mathrm{~g})$ and dry weight $(0.27 \mathrm{~g})$ as compared with top sprinkle irrigation (Figure 2E,F). The root length, total root volume, average root diameter, and number of root hairs of tomato seedlings increased under the influence of ebb-and-flow irrigation by $62.54 \%, 15.61 \%, 93.81 \%, 9.41 \%$, and $49.81 \%$, respectively, compared with those that received overhead irrigation (TSI) (Figure 2G,I-K). However, roof surface area remained unchanged with changed irrigation strategy (Figure $2 \mathrm{H}$ ). Leaf weight ratio, root weight ratio, and root-to-shoot ratio of tomato seedlings was positively influenced by ebb-and-flow irrigation (Figure 2L-N). Overall, plants receiving ebb-and-flow irrigation exhibited $13.85 \%, 23.25 \%$, and $12.74 \%$ increases in leaf weight ratio, root weight ratio, and root-to-shoot ratio compared with control, respectively.

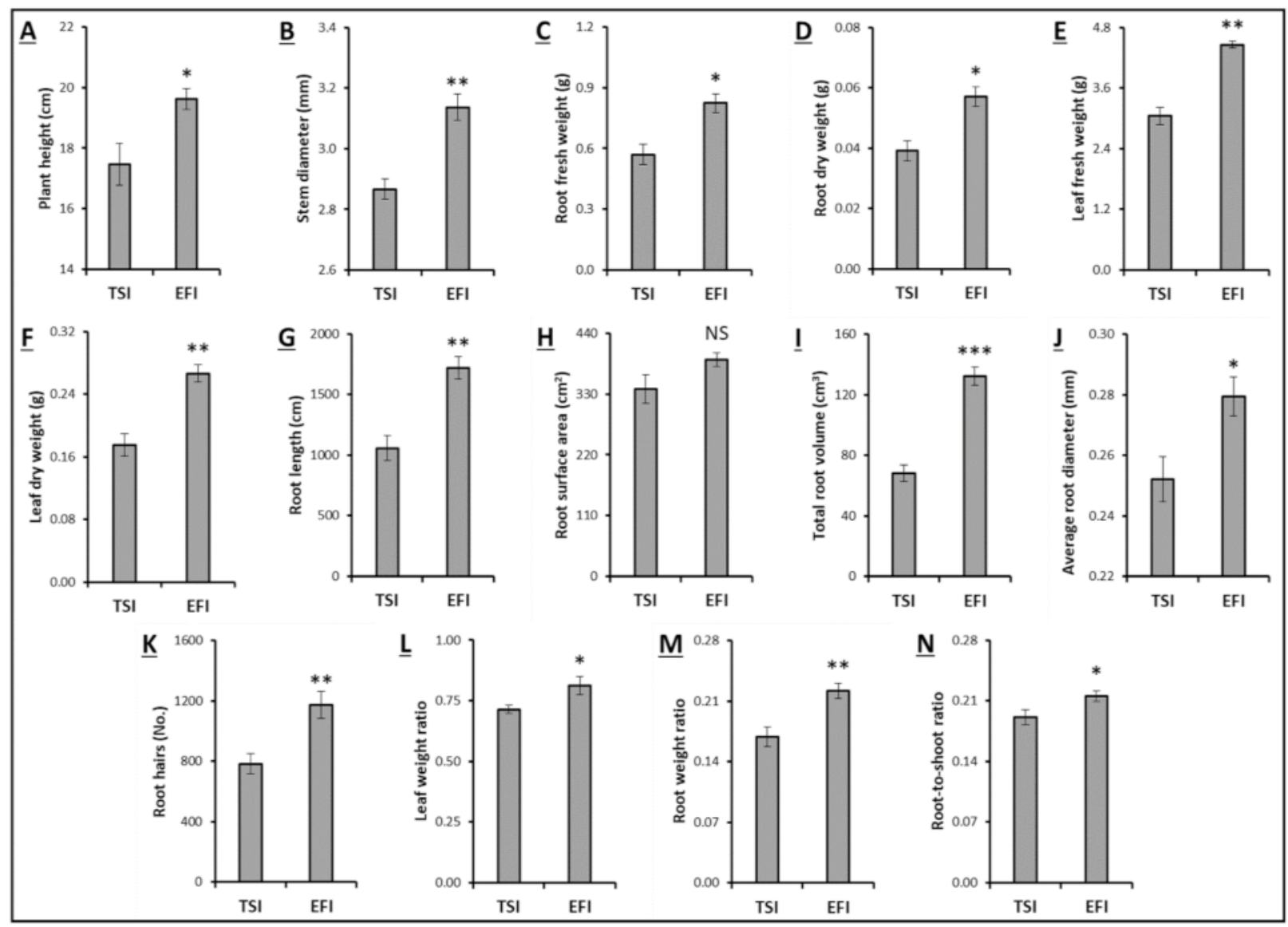

Figure 2. Effect of top sprinkle (TSI) and ebb-and-flow (EFI) irrigation on morphological attributes of tomato seedlings. Vertical bars indicate means $\pm \operatorname{SE}(n=3,10$ plants per replicate). The ${ }^{*}{ }^{* *}$ and ${ }^{* *}$ represent significance at $p \leq 0.05, p \leq 0.01$ and $p \leq 0.001$, respectively, according to Student's t-test. NS-not significant.

\subsection{Physiological Attributes}

At 35 DAS, the photosynthetic rate (Pn), stomatal conductance (Gs), and transpiration rate $(T r)$ of tomato seedlings were $8.813 \mu \mathrm{mol} \cdot \mathrm{m}^{-2} \cdot \mathrm{s}^{-1}, 0.606 \mathrm{mmol} \cdot \mathrm{m}^{-2} \cdot \mathrm{s}^{-1}$, and $1.341 \mathrm{mmol} \cdot \mathrm{m}^{-2} \cdot \mathrm{s}^{-1}$ under ebb-and-flow irrigation, and significantly $(p \leq 0.01)$ increased by $28.38 \%, 21.71 \%$, and $19.79 \%$ compared with the top sprinkle irrigation treatment, respectively (Figure 3A-C). Water use efficiency (WUE) of tomato seedlings was $7.409 \mu \mathrm{mol} \cdot \mathrm{mmol}^{-1}$ 
under the influence of ebb-and-flow irrigation, significantly $(p \leq 0.05)$ lower than that of the plants receiving top sprinkle irrigation (Figure 3D).

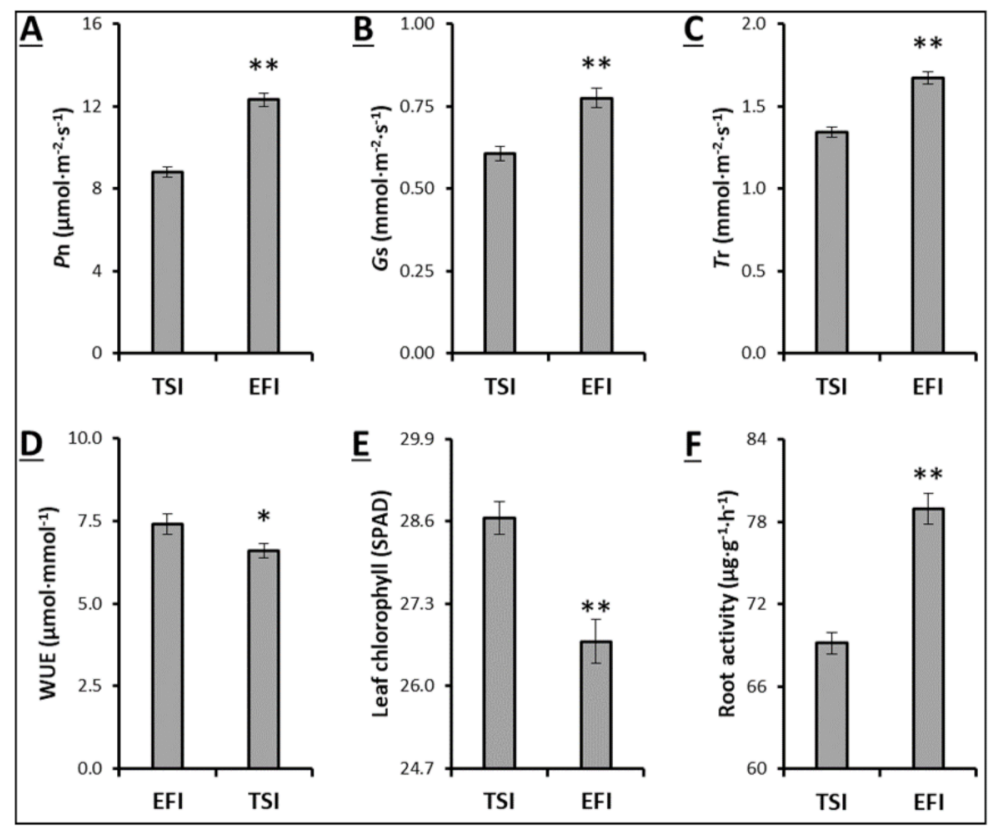

Figure 3. Effect of top sprinkle (TSI) and ebb-and-flow (EFI) irrigation on physiological attributes of tomato seedlings. Vertical bars indicate means $\pm \mathrm{SE}(n=3,10$ plants per replicate). The ${ }^{*}$ and ${ }^{* *}$ represent significance at $p \leq 0.05$ and $p \leq 0.01$, respectively, according to Student's $t$-test.

Chlorophyll content in leaves is an important index to reflect the photosynthetic capacity of the plants. The SPAD values depicting the chlorophyll content of tomato leaves were 28.66 and 26.70 under ebb-and-flow and top sprinkler irrigation, respectively (Figure 3E). Similarly, the root activity of tomato seedlings grown under ebb-and-flow irrigation system was $78.92 \mu \mathrm{g} \cdot \mathrm{g}^{-1} \cdot \mathrm{h}^{-1}$, which was $14.15 \%$ more as compared with the plants receiving top sprinkle irrigation treatment (Figure 3F).

\subsection{Enzymes Activity Assay}

Tomato plants grown under ebb-and-flow irrigation showed significantly $(p \leq 0.01)$ increased SOD, POD, CAT, GR, APX, and cellulase activities as compared to those receiving top sprinkle irrigation (Figure 3). The SOD, POD, and CAT activities of tomato roots under ebb-and-flow irrigation were $96.75,705.67$, and $10.67 \mathrm{U} \cdot \mathrm{g}^{-1}$ protein, respectively, which were $12.99 \%, 16.98 \%$, and $18.25 \%$ higher than those plants grown under top sprinkle irrigation system (Figure $4 \mathrm{~A}-\mathrm{C}$ ). Similarly, the plants receiving ebb-and-flow irrigation showed $46.51 \%$ and $28.18 \%$ increases in root GR and APX activities as compared with the top sprinkle irrigation treatment (Figure 4D,E). The activity of ACC synthase of tomato roots receiving ebb-and-flow irrigation was $21.6760745 \mathrm{U} \cdot \mathrm{mg}^{-1}$ protein, which was significantly $(p \leq 0.05)$ higher than that of top sprinkle irrigation treatment (Figure 4F). The cellulase activity of tomato roots under ebb-and-flow irrigation was $0.0745 \mathrm{U} \cdot \mathrm{g}^{-1}$ protein, which was significantly $(\mathrm{p} \leq 0.01)$ higher than those plants grown under top sprinkle irrigation (Figure 4G). A 6.39\% reduction was observed in the MDA content of tomato roots when treated with the ebb-and-flow irrigation strategy (Figure $4 \mathrm{H}$ ). 

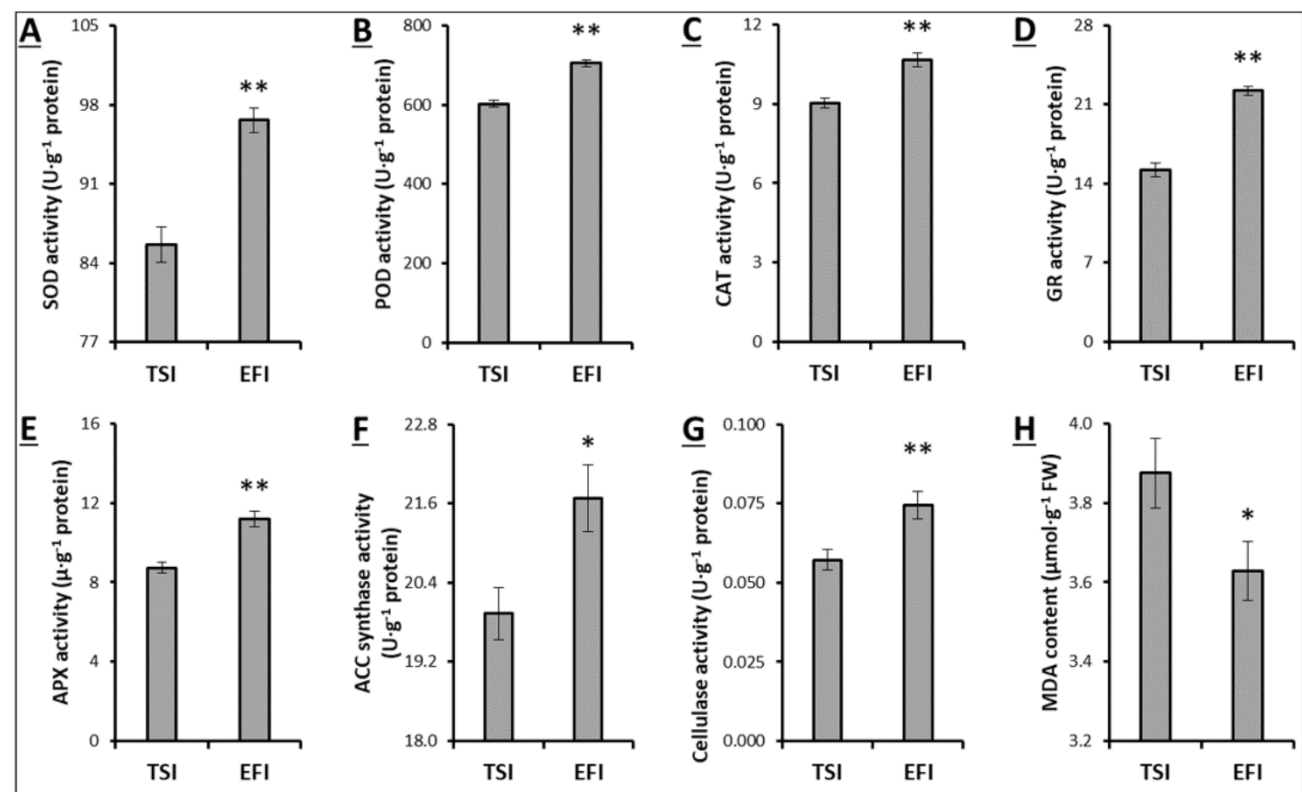

Figure 4. Effect of top sprinkle (TSI) and ebb-and-flow (EFI) irrigation on activities of SOD (A), POD (B), CAT (C), GR (D), APX (E), ACC synthase (F) and callulase (G), and MDA content $(\mathbf{H})$ of tomato root. Vertical bars indicate means $\pm \mathrm{SE}(n=3)$. The ${ }^{*}$ and ${ }^{* *}$ represent significance at $p \leq 0.05$ and $p \leq 0.01$, respectively, according to Student's $t$-test.

\subsection{Transcript Profiling of Genes Related to the Metabolism of Tomato Root Softening Enzymes}

A total of five genes related to SOD metabolism were identified through transcriptome data analysis of tomato roots. The genetic expression of SISOD1-3 was significantly $(p \leq 0.05)$ up-regulated in tomato roots under the influence of ebb-and-flow irrigation as compared with top sprinkle irrigation. Meanwhile, transcript levels of SISOD4 and SISOD4 remained unchanged with irrigation treatments $(p \leq 0.05)$ (Figure 5).

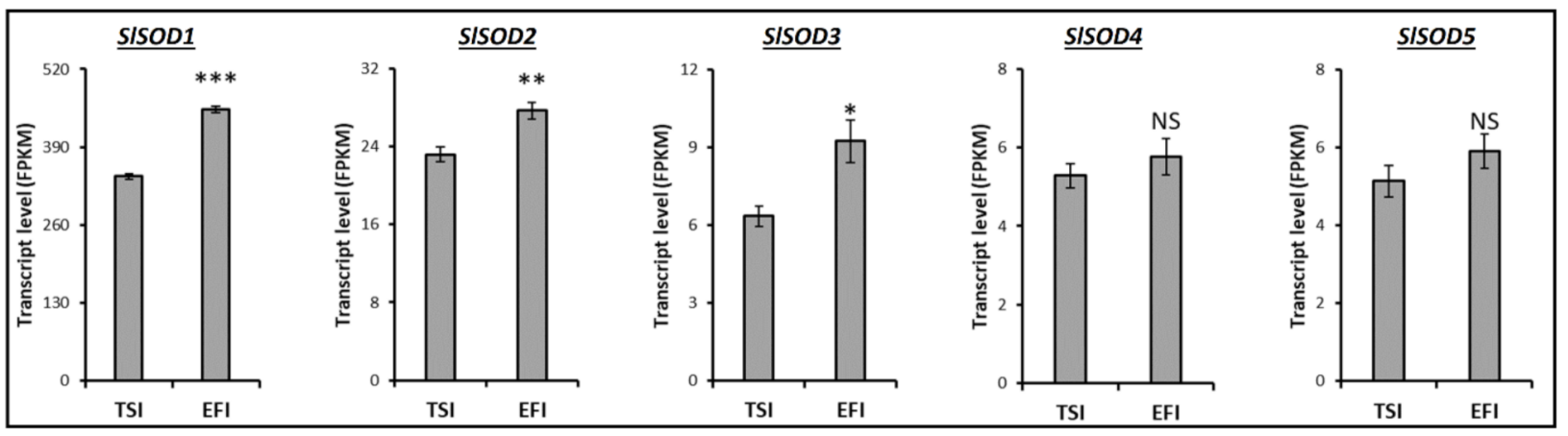

Figure 5. Effect of top sprinkle (TSI) and ebb-and-flow (EFI) irrigation on transcript profiling of SOD genes in tomato root. Vertical bars indicate means $\pm \mathrm{SE}$ (3 biological and 3 techincal replicates). The ${ }^{*}{ }^{* *}$ and ${ }^{* * *}$ represent significance at $p \leq 0.05, p \leq 0.01$ and $p \leq 0.001$, respectively, according to Student's $t$-test. NS-not significant.

Among 16 POD genes, the genetic expressions of SlPOD2, SIPOD7, SIPOD8, and SIPOD13 were up-regulated, while SIPOD1, SIPOD3, SIPOD5, SIPOD9, SIPOD11, and SIPOD16 were significantly down-regulated under the influence of ebb-and-flow irrigation as compared with top sprinkle irrigation. The transcript levels of SIPOD4, SIPOD6, SIPOD10, SIPOD12, SIPOD14, and SIPOD15 remained almost the same $(p \leq 0.05)$ in roots of the tomato seedlings grown under both irrigation systems (Figure 6). 


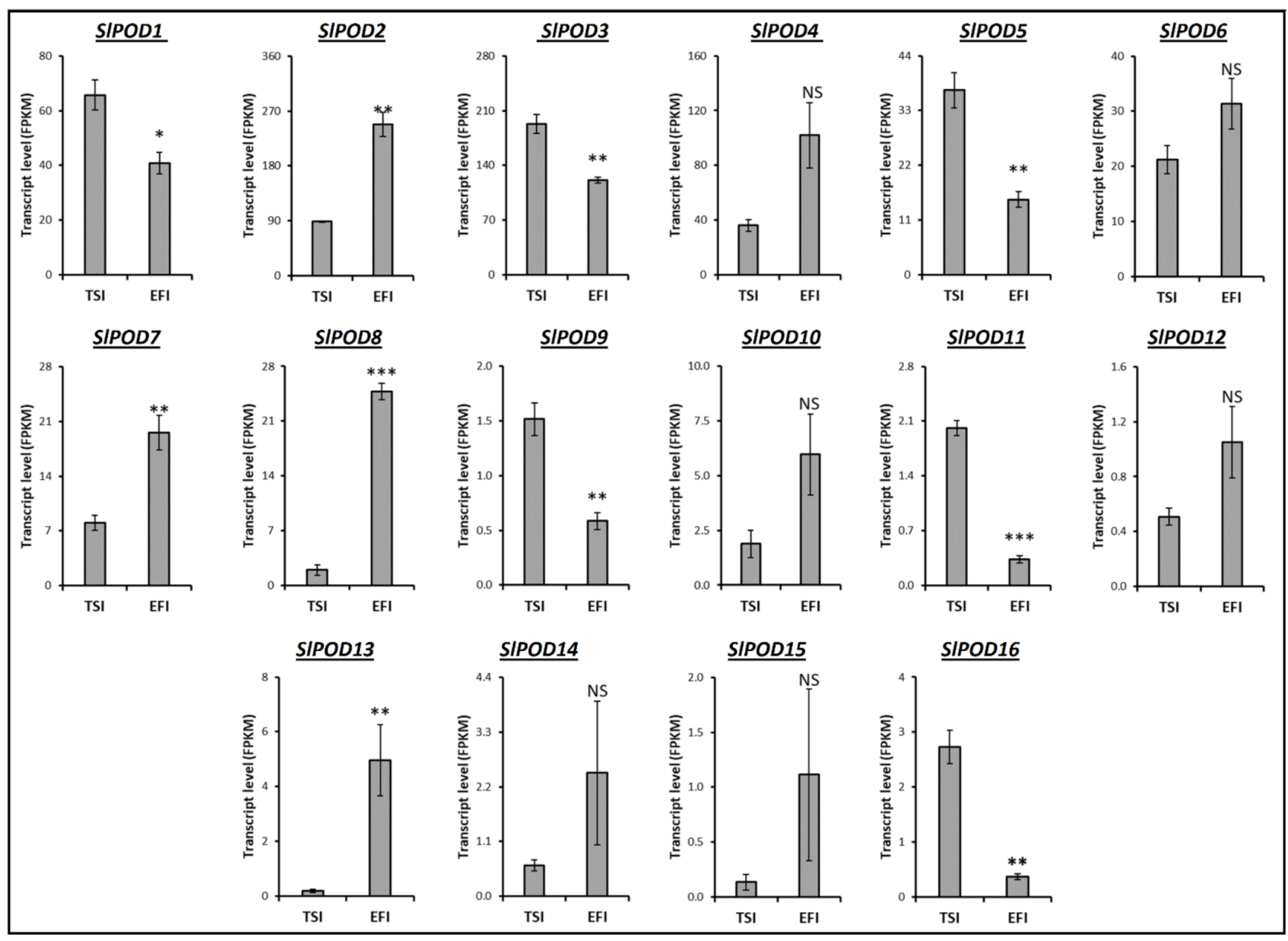

Figure 6. Effect of top sprinkle (TSI) and ebb-and-flow (EFI) irrigation on transcript profiling of POD genes in tomato root. Vertical bars indicate means $\pm \mathrm{SE}$ ( 3 biological and 3 techincal replicates). The ${ }^{*}{ }^{* *}$ and ${ }^{* * *}$ represent significance at $p \leq 0.05, p \leq 0.01$ and $p \leq 0.001$, respectively, according to Student's $t$-test. NS-not significant.

In the case of CAT genes, the genetic expression of only one gene (SlCAT1) was significantly $(p \leq 0.05)$ up-regulated, while SlCAT4-6 showed significantly $(p \leq 0.01)$ downregulated expression under the influence of ebb-and-flow irrigation as compared with top sprinkle irrigation. The transcript levels of SlCAT2-3 remained unchanged $(p \leq 0.05)$ in roots of the tomato seedlings grown under both irrigation systems (Figure 7).

There was only one gene (SIGR1) identified as responsible for GR metabolism through transcriptome data analysis of tomato roots. The expression level of SlGR1 was significantly reduced $(p \leq 0.05)$ under the effect of the ebb-and-flow irrigation system as compared with the top sprinkle irrigation strategy (Figure 8).

In the case of APX genes, the genetic expression of only one gene (SlAPX4) was significantly ( $p \leq 0.05)$ up-regulated, while SlAPX1-2 showed significantly $(p \leq 0.05)$ downregulated expression under the influence of ebb-and-flow irrigation as compared with top sprinkle irrigation. The transcript level of SIAPX3 remained non-significantly ( $p \leq 0.05)$ different in plants grown under both irrigation systems (Figure 9). 


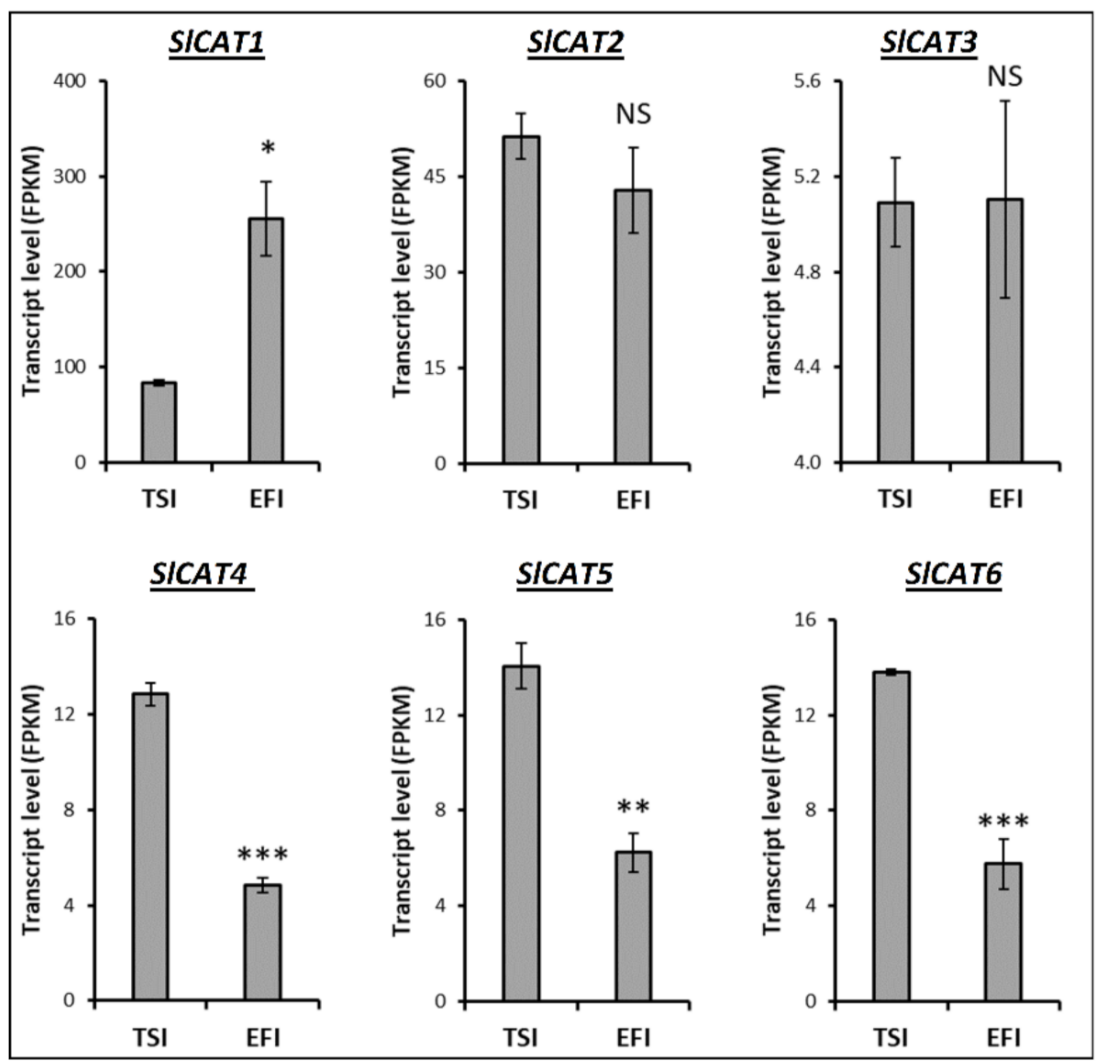

Figure 7. Effect of top sprinkle (TSI) and ebb-and-flow (EFI) irrigation on transcript profiling of CAT genes in tomato root. Vertical bars indicate means \pm SE (3 biological and 3 techincal replicates). The ${ }^{*}{ }^{* *}$ and ${ }^{* * *}$ represent significance at $p \leq 0.05, p \leq 0.01$ and $p \leq 0.001$, respectively, according to Student's $t$-test. NS-not significant.

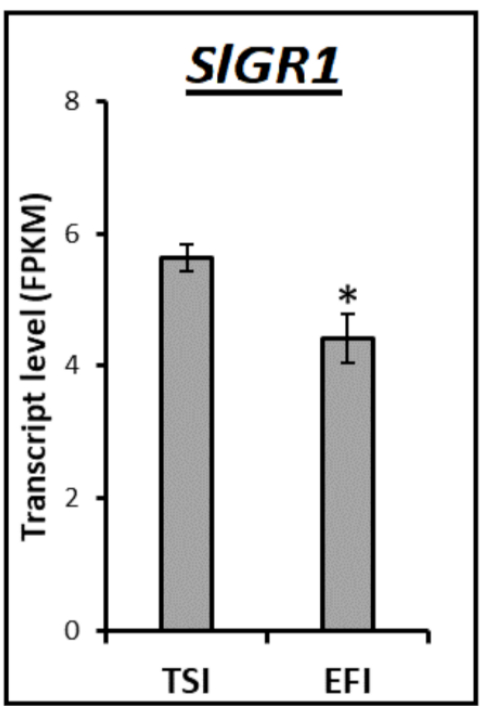

Figure 8. Effect of top sprinkle (TSI) and ebb-and-flow (EFI) irrigation on transcript level of GR gene in tomato root. Vertical bars indicate means \pm SE (3 biological and 3 techincal replicates). The * represents significance at $p \leq 0.05$, according to Student's $t$-test. 


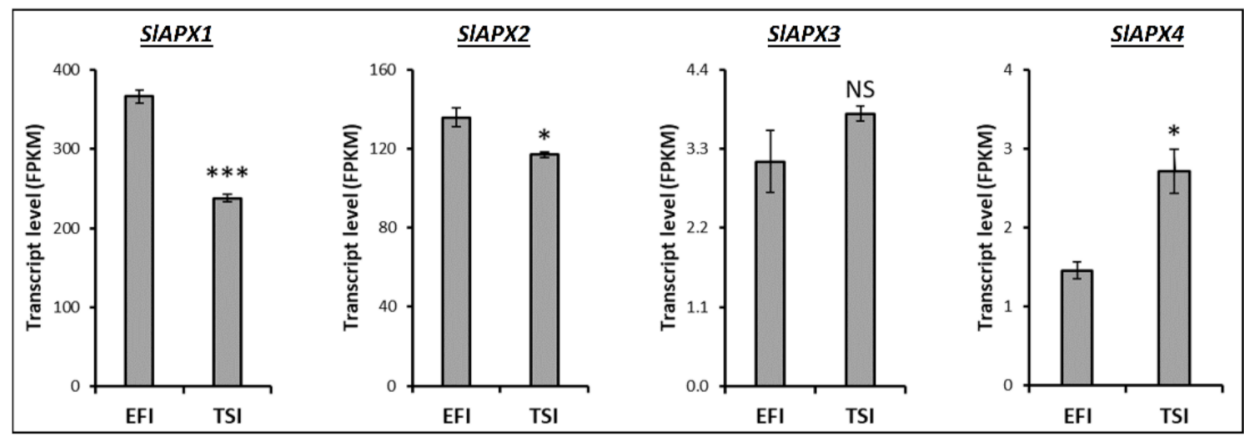

Figure 9. Effect of top sprinkle (TSI) and ebb-and-flow (EFI) irrigation on transcript profiling of APX genes in tomato root. Vertical bars indicate means $\pm \mathrm{SE}$ (3 biological and 3 techincal replicates). The ${ }^{*}$ and ${ }^{* * *}$ represent significance at $p \leq 0.05$ and $p \leq 0.001$, respectively, according to Student's $t$-test. NS-not significant.

There were seven genes identified as responsible for ACC synthase metabolism through transcriptome data analysis of tomato roots. The transcript levels of three genes (SlACC2, SlACC5, SlACC6) were significantly $(p \leq 0.05)$ up-regulated, while two genes (SlACC1 and SIACC4) showed significantly $(p \leq 0.001)$ down-regulated expression under the influence of ebb-and-flow irrigation as compared with top sprinkle irrigation. The transcript levels of SlACC3 and SlACC7 did not statistically significantly differ between irrigation treatments (Figure 10).

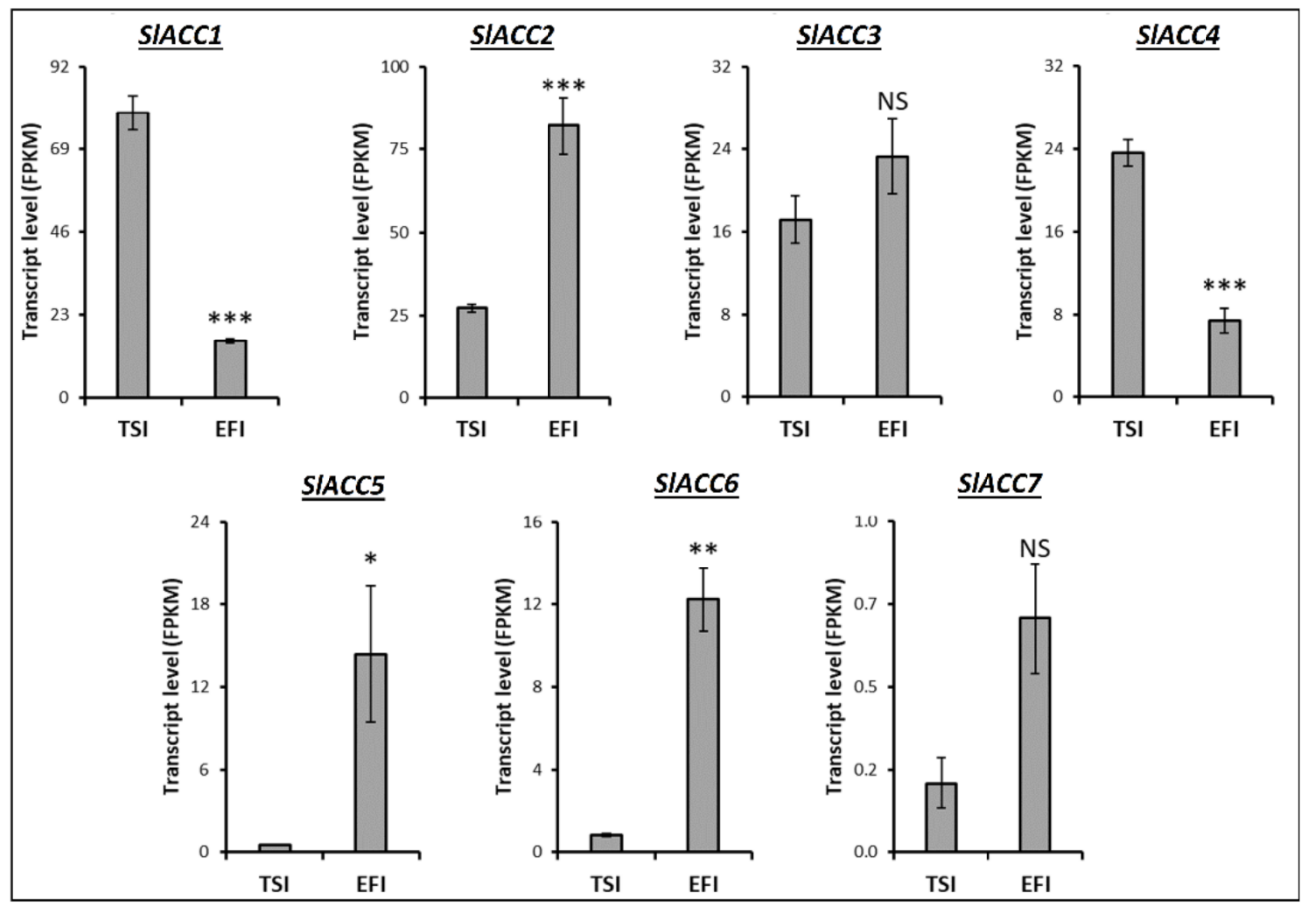

Figure 10. Effect of top sprinkle (TSI) and ebb-and-flow (EFI) irrigation on transcript profiling of ACC synthase genes in tomato roots. Vertical bars indicate means \pm SE ( 3 biological and 3 techincal replicates). The ${ }^{*}{ }^{* *}$ and ${ }^{* * *}$ represent significance at $p \leq 0.05, p \leq 0.01$ and $p \leq 0.001$, respectively, according to Student's $t$-test. NS-not significant.

In total, six genes were identified as being responsible for cellulase metabolism through transcriptome data analysis of tomato roots. The transcript level of only one gene (SlCesA4) was significantly ( $p \leq 0.05)$ up-regulated, and one gene (SlCesA1) was significantly $(p \leq 0.05)$ down-regulated under the influence of ebb-and-flow irrigation as 
compared with top sprinkle irrigation. The transcript levels of SlCesA2,3,5,6 remained nonsignificantly $(p \leq 0.05)$ different in plants grown under both irrigation systems (Figure 11).
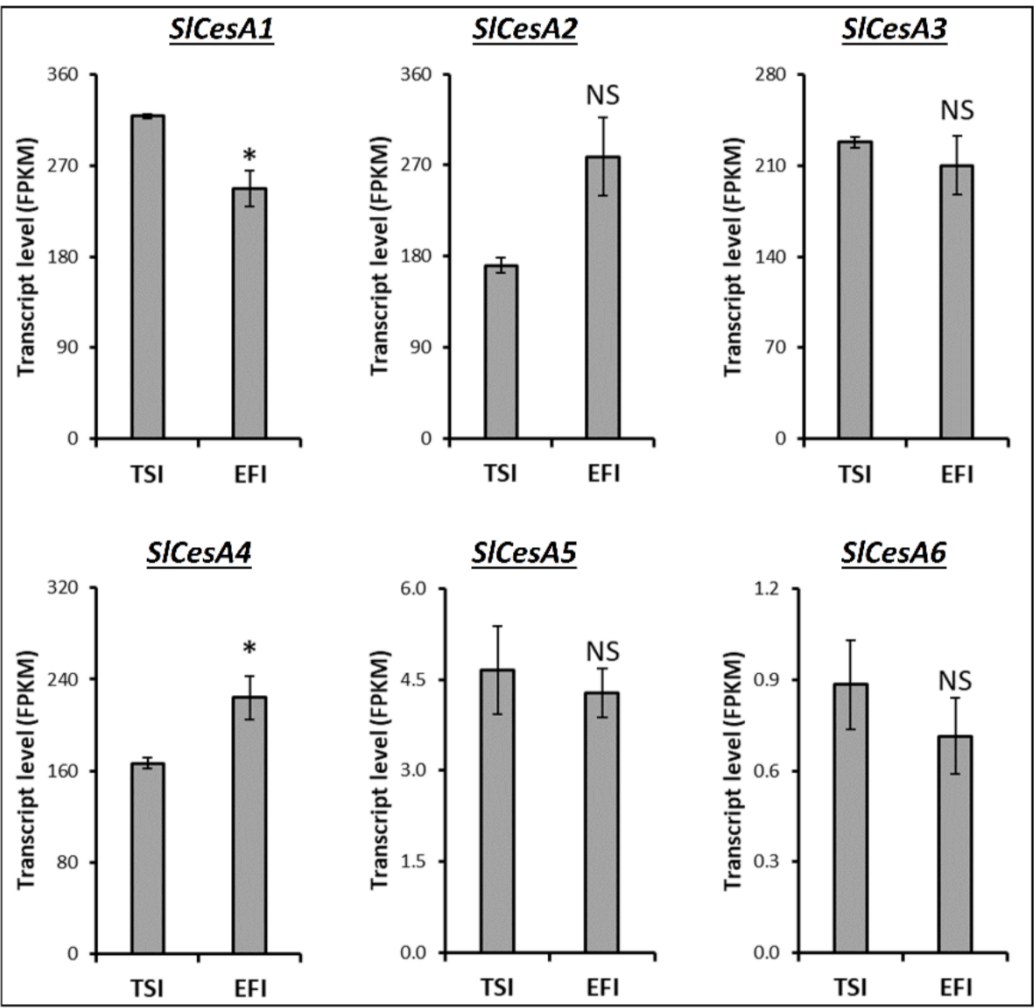

Figure 11. Effect of top sprinkle (TSI) and ebb-and-flow (EFI) irrigation on transcript profiling of cellulase metabolism-related genes in tomato roots. Vertical bars indicate means $\pm \mathrm{SE}$ (3 biological and 3 techincal replicates). The ${ }^{*}$ represents significance at $p \leq 0.05$, according to Student's $t$-test. NS-not significant.

\subsection{Pearson (n) Correlation between Root-Softening Enzymes Activities and Transcript Profiling of} Their Metabolism-Related Genes

The correlation between "root-softening enzymes activities (SOD, POD, CAT, GR, APX, ACC synthase and cellulase) and MDA content" and "transcript profiling of their metabolism-related genes" in the roots of tomato seedlings was analysed (Figure 12). The SOD activity was significantly $(p \leq 0.05)$ positively correlated with the transcript levels of SISOD1, SIPOD7, SIPOD8, SIPOD12, SIPOD13, SIAPX1, and SlAPX2. The POD activity was positively associated with SIPOD2, SIPOD8, SlCAT1, SIACC2, SIACC5, and SlACC6. Similarly, CAT activity was positively and significantly $(p \leq 0.05)$ correlated with SlSOD1, SISOD2, SIPOD2, SIPOD7, SIPOD8, SlPOD13, SlCAT1, SlAPX1, SlACC2, SIACC5, SlACC6, and SlACC7. The activity of GR enzyme was positively associated with the expressions of SlSOD1, SlSOD2, SlPOD2, SlPOD7, SlPOD8, SlPOD13, SlCAT1, SlAPX1, SlACC5, and SlACC6.

The correlation analysis showed that APX activity was positively associated with the transcript levels of SlCAT1, SlACC5, SlACC6, SlACC7, and SlCesA4. Interestingly, ACC synthase activity was positively and significantly correlated with the genetic expressions of SIPOD14, SIPOD15, and SIAPX2. Similarly, cellulase activity positively correlated with SIPOD4, SlACC2, and SlCesA2. The MDA content showed the opposite trend to all other root-softening enzymes. It was negatively correlated with SISOD5 while it showed a significantly $(p \leq 0.05)$ positive correlation with SlCesA5. 


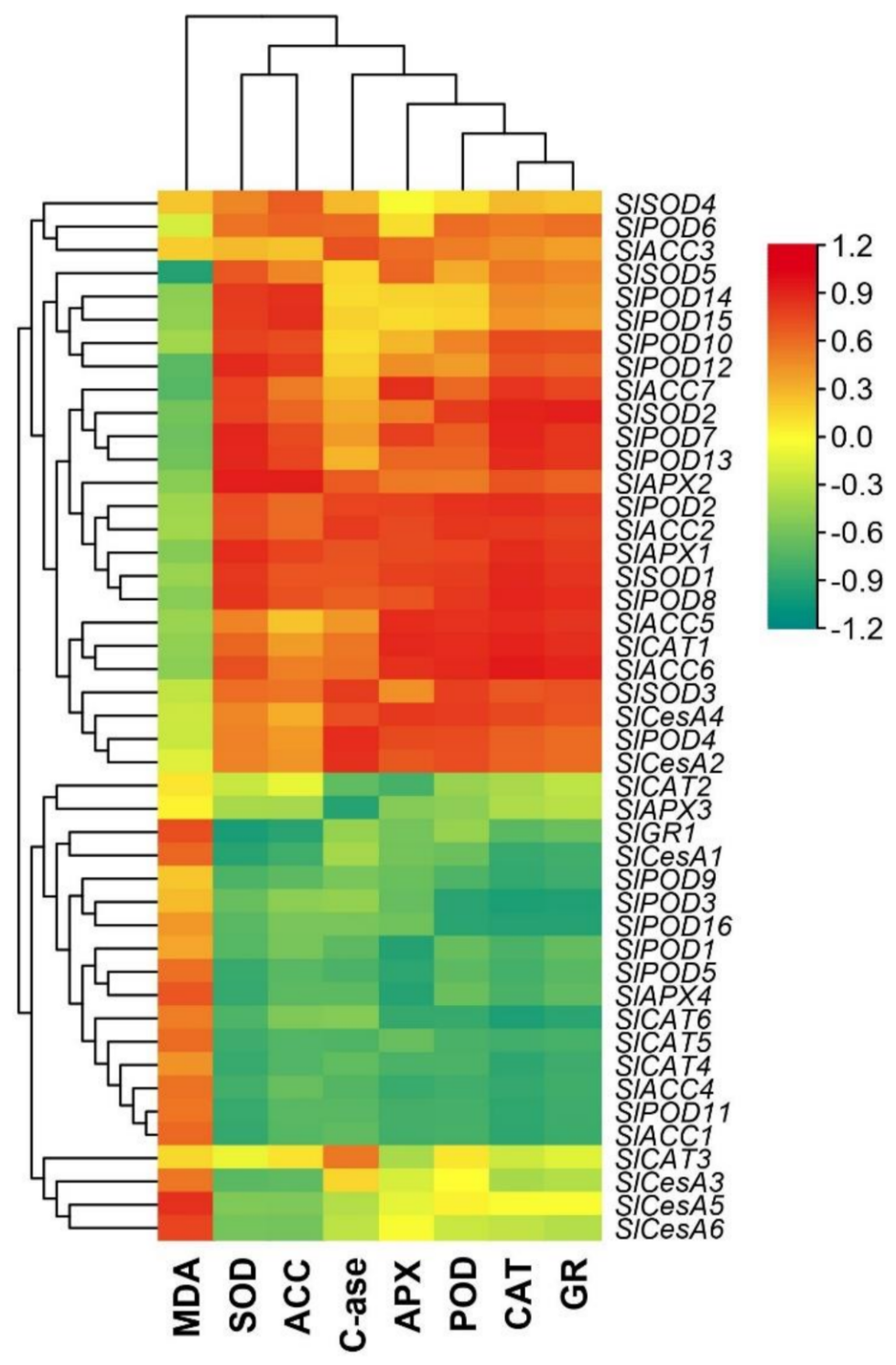

Figure 12. The heat map showing Pearson $(n)$ correlation between root-softening enzymes activities and transcript profiling of their metabolism-related genes. Correlation coefficient values were determined with Pearson (n) method using IBM SPSS software (ver. 17.0) and visualized through a heat-map using TBtools software (ver. 0.6655). Color codes: red-higher correlation; green-lower correlation.

\section{Discussion}

Compared to top sprinkle irrigated plants, ebb-and-flow sub-irrigated tomatoes increased plant biomass. These responses have been ascribed to a more uniform watering [52], lower water stress, and to an improved nutrition status due to a higher nutrient retention in the growing medium [53] in sub-irrigated when compared to top sprinkle-irrigated tomato plants. Recent studies on tomato and cucumber show that under ebb-and-flow irrigation, the plant growth potential is strong, the growth period is advanced, and the bottom water supply can enhance the quality of plug seedlings [54,55]. In this experiment, it was found that compared with the traditional top sprinkle irrigation, the ebb-and-flow irrigation treatment could significantly increase the stem diameter, as well as the root dry and fresh weight of tomato seedlings, indicating the importance of the ebb-and-flow irrigation strategy. At the same time, the total root length, root volume, and average root diameter of tomato seedlings under ebb-and-flow irrigation were significantly higher than 
those under traditional top sprinkler irrigation, indicating that the subirrigation method is conducive to promote the rooting of tomato seedlings.

In the process of seedling raising, water management is very important for plant growth [56]. Too much water can cause waterlogging and less water will lead to drought stress [57,58]. The cell membranes and ROS system are severely affected by stress [59]. Malondialdehyde (MDA) is the final product of peroxidation of unsaturated fatty acids in plant cell membrane [60-62]. The higher its content, the greater the degree of membrane damage [63]. The SOD, POD, and CAT are the most important antioxidant enzymes in plants $[64,65]$. They interact to decompose free radicals into water and oxygen [66,67]. At the same time, they cooperate with the ascorbic acid (AsA) and glutathione (GSH) cycle to regulate reactive oxygen species metabolism [67] and maintain the redox balance of plant cells $[68,69]$. APX takes AsA as substrate and scavenges $\mathrm{H}_{2} \mathrm{O}_{2}$ with the help of AsA-GSH cycle system located on chloroplast membrane participated by glutathione dehydrogenase reductase (DHAR) and glutathione reductase (GR) [70]. Higher contents of APX and GSH help to improve plant defense mechanism [71]. The research shows that when tomato is subjected to water stress, the antioxidant enzyme activities of plant leaves and roots will increase with the aggravation of water stress to eliminate the adverse effects of free radicals [72]. In this experiment, it was found that the activities of SOD, POD, and CAT in tomato roots sub-irrigated with ebb-and-flow irrigation were higher than those irrigated with top sprinkle irrigation, but the content of MDA decreased significantly, indicating that the tomato roots treated with EFI maintained high growth activity, which could effectively remove the accumulation of MDA and reduce the damage of membrane lipid peroxidation. At the same time, roots of tomato plants grown under the ebb-and-flow subirrigation system maintained high APX and GR activities, which was conducive to enhance the antioxidant capacity of tomato seedlings. The stem diameter and root fresh weight were correlated with SOD, POD, CAT, and GR, which also reflect that the plants grew better under ebb-and-flow subirrigation and maintained high antioxidant enzyme activity.

Chlorophyll content is an important parameter reflecting the photosynthetic capacity of crops [73,74]. Net photosynthetic rate (Pn) reflects the plant photosynthetic capacity [75] and stomatal conductance (Gs) is closely related to plant stress resistance [76]. The water content of soil or substrate is closely related to plant photosynthesis [77,78]. Under moderate water stress, the leaf stomata remain closed, resulting in a decrease of evaporation and decrease of Pn and Gs [79]. In this experiment, the Pn and Gs of tomato seedlings grown under ebb-and-flow subirrigation were higher than those under top sprinkle irrigation, indicating that tomato plants maintained high photosynthetic capacity under EFI, while TSI treatment might lead to drought due to uneven watering.

Root activity is an important indicator to reflect the strength of the plant root system [80]. It is closely related to the plant life cycle and can reflect the dynamic relationship between root growth and water supply [80,81]. Studies on maize [82] and duckweed [83] show that the root activity of plants decreases or increases first and then decreases under drought stress. In this experiment, the root activity of tomato seedlings grown under an ebb-and-flow irrigation system was significantly higher than those irrigated with top sprinkle irrigation, maintaining vigorous metabolic activity and indicating that the water supply of EFI treatment was more uniform, and the effects of drought and other uneven water changes caused by TSI treatment were reduced.

\section{Conclusions}

This experiment was designed to investigate the comparison between traditional top sprinkle irrigation and ebb-and-flow subirrigation systems in terms of their effects on plant growth and the root morphology of tomato. The results indicate that ebb-and-flow subirrigation is a feasible system for soilless-cultivated tomato with no negative effects on its growth. Ebb-and-flow subirrigation of tomato resulted in beneficial changes to root morphology, as evidenced by increased root length, root surface area, root volume, average root diameter, and number of root hairs. The ebb-and-flow subirrigation strategy also 
enhanced the activities of root-softening enzymes, i.e., SOD, POD, CAT, GR, APX, ACC synthase, and cellulase, resulting in better plant growth. Transcriptomic analysis of tomato roots revealed that ebb-and-flow subirrigation system caused significant variation in the expression of genes related to the biosynthesis of the aforementioned enzymes. Thus, ebb-and-flow subirrigation is a promising treatment to reduce water stress and improve the overall growth of tomato plants. This research laid the basis for further elucidation of the mechanism behind the coordinated growth of above-ground and underground plant parts under the influence of different irrigation techniques.

Supplementary Materials: The following are available online at https:/ / www.mdpi.com/article/10.3 390/agronomy12020494/s1, Table S1: Gene IDs, FPKM values and description of studied tomato genes.

Author Contributions: Conceptualization, K.W. and J.X.; methodology, K.W. and S.S.; software, K.W. and M.M.A.; validation, M.M.A. and F.C.; formal analysis, K.W. and M.M.A.; investigation, S.S. and K.P.; resources, J.X. and K.P.; data curation, M.M.A.; writing-original draft preparation, K.W. and M.M.A.; writing-review and editing, K.P., S.S., J.X. and F.C.; supervision, J.X. and F.C.; project administration, J.X. and K.W.; funding acquisition, J.X. and K.W. All authors have read and agreed to the published version of the manuscript.

Funding: This research was funded by "China Agriculture Research System, grant number CARS-23" and "Doctoral Research Start Project of Wenzhou Vocational College of Science and Technology, grant number 201903".

Data Availability Statement: Not applicable.

Conflicts of Interest: The authors declare no conflict of interest.

\section{References}

1. Bai, Y.; Lindhout, P. Domestication and Breeding of Tomatoes: What have We Gained and What Can We Gain in the Future? Ann. Bot. 2007, 100, 1085-1094. [CrossRef] [PubMed]

2. Yousef, A.F.; Ali, M.M.; Rizwan, H.M.; Gad, A.G.; Liang, D.; Binqi, L.; Kalaji, H.M.; Wróbel, J.; Xu, Y.; Chen, F. Light quality and quantity affect graft union formation of tomato plants. Sci. Rep. 2021, 11, 9870. [CrossRef]

3. Al-Muhtaseb, A.H.; Al-Harahsheh, M.; Hararah, M.; Magee, T.R.A. Drying characteristics and quality change of unutilized-protein rich-tomato pomace with and without osmotic pre-treatment. Ind. Crops Prod. 2010, 31, 171-177. [CrossRef]

4. $\quad$ Ali, M.M.; Waleed Shafique, M.; Gull, S.; Afzal Naveed, W.; Javed, T.; Yousef, A.F.; Mauro, R.P. Alleviation of Heat Stress in Tomato by Exogenous Application of Sulfur. Horticulturae 2021, 7, 21. [CrossRef]

5. Yousef, A.F.; Xu, Y.; Chen, F.; Lin, K.; Zhang, X.; Guiamba, H.; Ibrahim, M.M.; Rizwan, H.M.; Ali, M.M. The influence of LEDs light quality on the growth pigments biochemical and chlorophyll fluorescence characteristics of tomato seedlings (Solanum lycopersicum L.). Fresenius Environ. Bull. 2021, 30, 3575-3588.

6. Yousef, A.F.; Ali, M.M.; Rizwan, H.M.; Tadda, S.A.; Xu, Y.; Kalaji, H.M.; Yang, H.; Ahmed, M.A.A.; Wro, J.; Chen, F. Photosynthetic apparatus performance of tomato seedlings grown under various combinations of LED illumination. PLoS ONE 2021, 16, 1-17. [CrossRef]

7. Ali, M.M.; Javed, T.; Mauro, R.P.; Shabbir, R.; Afzal, I.; Yousef, A.F. Effect of Seed Priming with Potassium Nitrate on the Performance of Tomato. Agriculture 2020, 10, 498. [CrossRef]

8. Richards, D.L.; Reed, D.W. New Guinea Impatiens Growth Response and Nutrient Release from Controlled-release Fertilizer in a Recirculating Subirrigation and Top-watering System. HortScience 2004, 39, 280-286. [CrossRef]

9. Zheng, Y.; Graham, T.; Richard, S.; Dixon, M. Potted Gerbera Production in a Subirrigation System Using Low-concentration Nutrient Solutions. HortScience 2004, 39, 1283-1286. [CrossRef]

10. Zheng, Y.; Graham, T.; Richard, S.; Dixon, M. Can Low Nutrient Strategies be Used for Pot Gerbera Production in Closed-Loop Subirrigation? Acta Hortic. 2005, 365-372. [CrossRef]

11. Ferrarezi, R.S.; Weaver, G.M.; van Iersel, M.W.; Testezlaf, R. Subirrigation: Historical Overview, Challenges, and Future Prospects. Horttechnology 2015, 25, 262-276. [CrossRef]

12. Araus, J.L.; Rezzouk, F.Z.; Thushar, S.; Shahid, M.; Elouafi, I.A.; Bort, J.; Serret, M.D. Effect of irrigation salinity and ecotype on the growth, physiological indicators and seed yield and quality of Salicornia europaea. Plant Sci. 2021, 304, 110819. [CrossRef] [PubMed]

13. Fereres, E.; Soriano, M.A. Deficit irrigation for reducing agricultural water use. J. Exp. Bot. 2006, 58, 147-159. [CrossRef] [PubMed]

14. Morison, J.I.; Baker, N.; Mullineaux, P.; Davies, W. Improving water use in crop production. Philos. Trans. R. Soc. B Biol. Sci. 2008, 363, 639-658. [CrossRef] [PubMed]

15. Nadeem, M.; Li, J.; Yahya, M.; Sher, A.; Ma, C.; Wang, X.; Qiu, L. Research Progress and Perspective on Drought Stress in Legumes: A Review. Int. J. Mol. Sci. 2019, 20, 2541. [CrossRef] [PubMed] 
16. Parkash, V.; Singh, S.; Deb, S.K.; Ritchie, G.L.; Wallace, R.W. Effect of deficit irrigation on physiology, plant growth, and fruit yield of cucumber cultivars. Plant Stress 2021, 1, 100004. [CrossRef]

17. Leskovar, D.I. Root and Shoot Modification by Irrigation. Horttechnology 1998, 8, 510-514. [CrossRef]

18. Elmer, W.H.; Gent, M.P.N.; McAvoy, R.J. Partial saturation under ebb and flow irrigation suppresses Pythium root rot of ornamentals. Crop Prot. 2012, 33, 29-33. [CrossRef]

19. James, E.; van Iersel, M. Ebb and Flow Production of Petunias and Begonias as Affected by Fertilizers with Different Phosphorus Content. HortScience 2001, 36, 282-285. [CrossRef]

20. Buwalda, F.; Baas, R.; van Weel, P.A. A soilless ebb-and-flow system for all-year-round chrysanthemums. Acta Hortic. 1994, 361, 123-132. [CrossRef]

21. Naghedifar, S.M.; Ziaei, A.N.; Ansari, H. Numerical analysis of sensor-based flood-floor ebb-and-flow subirrigation system with saline water. Arch. Agron. Soil Sci. 2021, 67, 1285-1299. [CrossRef]

22. Poole, R.T.; Conover, C.A. Fertilizer Levels and Medium Affect Foliage Plant Growth in an Ebb and Flow Irrigation System. J. Environ. Hortic. 1992, 10, 81-86. [CrossRef]

23. Rouphael, Y.; Cardarelli, M.; Rea, E.; Colla, G. The influence of irrigation system and nutrient solution concentration on potted geranium production under various conditions of radiation and temperature. Sci. Hortic. 2008, 118, 328-337. [CrossRef]

24. Leskovar, D.I.; Boales, A.K. Plant Establishment Systems Affect Yield of Jalapeno Pepper. Acta Hortic. 1995, 412, 275-280. [CrossRef]

25. Leskovar, D.I.; Cantliffe, D.J. Comparison of Plant Establishment Method, Transplant, or Direct Seeding on Growth and Yield of Bell Pepper. J. Am. Soc. Hortic. Sci. 1993, 118, 17-22. [CrossRef]

26. Leskovar, D.I.; Cantliffe, D.J.; Stoffella, P.J. Transplant Production Systems Influence Growth and Yield of Fresh-market Tomatoes. J. Am. Soc. Hortic. Sci. 1994, 119, 662-668. [CrossRef]

27. Mahgoub, N.A.; Ibrahim, A.M.; Ali, O.M. Effect of different irrigation systems on root growth of maize and cowpea plants in sandy soil. Eurasian J. Soil Sci. 2017, 6, 374-379. [CrossRef]

28. Xuewen, X.; Huihui, W.; Xiaohua, Q.; Qiang, X.; Xuehao, C. Waterlogging-induced increase in fermentation and related gene expression in the root of cucumber (Cucumis sativus L.). Sci. Hortic. 2014, 179, 388-395. [CrossRef]

29. Zhang, P.; Lyu, D.; Jia, L.; He, J.; Qin, S. Physiological and de novo transcriptome analysis of the fermentation mechanism of Cerasus sachalinensis roots in response to short-term waterlogging. BMC Genom. 2017, 18, 649. [CrossRef]

30. Hattori, Y.; Nagai, K.; Furukawa, S.; Song, X.J.; Kawano, R.; Sakakibara, H.; Wu, J.; Matsumoto, T.; Yoshimura, A.; Kitano, H.; et al. The ethylene response factors SNORKEL1 and SNORKEL2 allow rice to adapt to deep water. Nature 2009, 460, 1026-1030. [CrossRef]

31. Kuroha, T.; Nagai, K.; Gamuyao, R.; Wang, D.R.; Furuta, T.; Nakamori, M.; Kitaoka, T.; Adachi, K.; Minami, A.; Mori, Y.; et al. Ethylene-gibberellin signaling underlies adaptation of rice to periodic flooding. Science 2018, 361, 181-186. [CrossRef]

32. Pan, J.; Sharif, R.; Xu, X.; Chen, X. Mechanisms of Waterlogging Tolerance in Plants: Research Progress and Prospects. Front. Plant Sci. 2021, 11, 2319. [CrossRef] [PubMed]

33. Fukao, T.; Barrera-Figueroa, B.E.; Juntawong, P.; Peña-Castro, J.M. Submergence and Waterlogging Stress in Plants: A Review Highlighting Research Opportunities and Understudied Aspects. Front. Plant Sci. 2019, 10, 340. [CrossRef] [PubMed]

34. Anee, T.I.; Nahar, K.; Rahman, A.; Mahmud, J.A.; Bhuiyan, T.F.; Alam, M.U.; Fujita, M.; Hasanuzzaman, M. Oxidative Damage and Antioxidant Defense in Sesamum indicum after Different Waterlogging Durations. Plants 2019, 8, 196. [CrossRef] [PubMed]

35. Habibullah, M.; Sarkar, S.; Islam, M.M.; Ahmed, K.U.; Rahman, M.Z.; Awad, M.F.; ElSayed, A.I.; Mansour, E.; Hossain, M.S. Assessing the Response of Diverse Sesame Genotypes to Waterlogging Durations at Different Plant Growth Stages. Plants 2021, 10, 2294. [CrossRef] [PubMed]

36. Kelei, W.; Youhe, Z.; Jianlei, S.; Zong'an, H.; Longjing, Z.; Jian, X. Application of dynamic water level management of ebb and flow irrigation for cucumber seedlings. Acta Agric. Zhejiangensis 2017, 29, 408-413.

37. Ali, M.M.; Anwar, R.; Malik, A.U.; Khan, A.S.; Ahmad, S.; Hussain, Z.; Hasan, M.U.; Nasir, M.; Chen, F. Plant Growth and Fruit Quality Response of Strawberry is Improved After Exogenous Application of 24-Epibrassinolide. J. Plant Growth Regul. 2021, 1-14. [CrossRef]

38. Fernandez, G.E.; Butler, L.M.; Louws, F.J. Strawberry Plant Growth Parameters and Yield among Transplants of Different Types and from Different Geographic Sources, Grown in a Plasticulture System. Horttechnology 2002, 12, 100-103. [CrossRef]

39. Chiariello, N.R.; Mooney, H.A.; Williams, K. Growth, carbon allocation and cost of plant tissues. In Plant Physiological Ecology; Springer: Dordrecht, The Netherlands, 1989; pp. 327-365.

40. Ogutu, B.O.; Dash, J.; Dawson, T.P. Developing a diagnostic model for estimating terrestrial vegetation gross primary productivity using the photosynthetic quantum yield and Earth Observation data. Glob. Chang. Biol. 2013, 19, 2878-2892. [CrossRef]

41. Steponkus, P.L.; Lanphear, F.O. Refinement of the Triphenyl Tetrazolium Chloride Method of Determining Cold Injury. Plant Physiol. 1967, 42, 1423-1426. [CrossRef]

42. Chao, Y.Y.; Chen, C.Y.; Huang, W.D.; Kao, C.H. Salicylic acid-mediated hydrogen peroxide accumulation and protection against Cd toxicity in rice leaves. Plant Soil 2010, 329, 327-337. [CrossRef]

43. El-Shabrawi, H.; Kumar, B.; Kaul, T.; Reddy, M.K.; Singla-Pareek, S.L.; Sopory, S.K. Redox homeostasis, antioxidant defense, and methylglyoxal detoxification as markers for salt tolerance in Pokkali rice. Protoplasma 2010, 245, 85-96. [CrossRef] [PubMed] 
44. Hasanuzzaman, M.; Hossain, M.A.; Fujita, M. Nitric oxide modulates antioxidant defense and the methylglyoxal detoxification system and reduces salinity-induced damage of wheat seedlings. Plant Biotechnol. Rep. 2011, 5, 353-365. [CrossRef]

45. Zhou, Y.; Ming, D.; Cui, J.; Chen, X.; Wen, Z.; Zhang, J.; Liu, H. Exogenous GSH protects tomatoes against salt stress by modulating photosystem II efficiency, absorbed light allocation and $\mathrm{H}_{2} \mathrm{O}_{2}$-scavenging system in chloroplasts. J. Integr. Agric. 2018, 17, 2257-2272. [CrossRef]

46. Nakano, Y.; Asada, K. Hydrogen Peroxide is Scavenged by Ascorbate-specific Peroxidase in Spinach Chloroplasts. Plant Cell Physiol. 1981, 22, 867-880. [CrossRef]

47. Cakmak, I.; Strbac, D.; Marschner, H. Activities of Hydrogen Peroxide-Scavenging Enzymes in Germinating Wheat Seeds. J. Exp. Bot. 1993, 44, 127-132. [CrossRef]

48. Heath, R.L.; Packer, L. Photoperoxidation in isolated chloroplasts. Arch. Biochem. Biophys. 1968, 125, 189-198. [CrossRef]

49. Zhang, Z.; Zheng, Z.; Cai, J.; Liu, Q.; Yang, J.; Gong, Y.; Wu, M.; Shen, Q.; Xu, S. Effect of cadmium on oxidative stress and immune function of common carp (Cyprinus carpio L.) by transcriptome analysis. Aquat. Toxicol. 2017, 192, 171-177. [CrossRef]

50. Ma, Q.; Yang, J. Transcriptome profiling and identification of functional genes involved in $\mathrm{H} 2 \mathrm{~S}$ response in grapevine tissue cultured plantlets. Genes Genom. 2018, 40, 1287-1300. [CrossRef]

51. Chen, C.; Chen, H.; Zhang, Y.; Thomas, H.R.; Frank, M.H.; He, Y.; Xia, R. TBtools: An Integrative Toolkit Developed for Interactive Analyses of Big Biological Data. Mol. Plant 2020, 13, 1194-1202. [CrossRef]

52. García-Santiago, J.C.; Valdez-Aguilar, L.A.; Cartmill, A.D.; Cartmill, D.L.; Juárez-López, P.; Díaz-Pérez, J.C. Subirrigation of Container-Grown Tomato I: Decreased Concentration of the Nutrient Solution Sustains Growth and Yield. Water 2019, 11, 2064. [CrossRef]

53. Pinto, J.R.; Chandler, R.A.; Dumroese, R.K. Growth, Nitrogen Use Efficiency, and Leachate Comparison of Subirrigated and Overhead Irrigated Pale Purple Coneflower Seedlings. HortScience 2008, 43, 897-901. [CrossRef]

54. Dong, C.J.; Li, Q.; Wang, L.L.; Shang, Q.M. Dynamic changes in bacterial communities in the recirculating nutrient solution of cucumber plug seedlings cultivated in an ebb-and-flow subirrigation system. PLoS ONE 2020, 15, e0232446. [CrossRef] [PubMed]

55. Li, Q.; Tian, Y.; Shang, Q.; Cao, L.; Dong, C. Effects of Irrigation Height on Water and Nitrogen Use Efficiency of Tomato Plug Seedlings under Ebb-and-Flow Irrigation. Acta Agric. Boreali-Sinica 2019, 34, 126-132. [CrossRef]

56. Leakey, R.R.B. Agroforestry-Participatory Domestication of Trees. In Multifunctional Agriculture; Elsevier: Amsterdam, The Netherlands, 2017; pp. 297-314.

57. Kozlowski, T.T.; Pallardy, S.G. Seed Germination and Seedling Growth. In Growth Control in Woody Plants; Elsevier: Amsterdam, The Netherlands, 1997; pp. 14-72.

58. Ali, M.M.; Yousef, A.F.; Li, B.; Chen, F. Effect of Environmental Factors on Growth and Development of Fruits. Trop. Plant Biol. 2021, 14, 226-238. [CrossRef]

59. Javed, T.; Ali, M.M.; Shabbir, R.; Anwar, R.; Afzal, I.; Mauro, R.P. Alleviation of Copper-Induced Stress in Pea (Pisum sativum L.) through Foliar Application of Gibberellic Acid. Biology 2021, 10, 120. [CrossRef]

60. Ayala, A.; Muñoz, M.F.; Argüelles, S. Lipid Peroxidation: Production, Metabolism, and Signaling Mechanisms of Malondialdehyde and 4-Hydroxy-2-Nonenal. Oxid. Med. Cell. Longev. 2014, 2014, 1-31. [CrossRef]

61. Li, X. FGFs in Injury Repair and Regeneration. In Fibroblast Growth Factors; Elsevier: Amsterdam, The Netherlands, 2018; pp. 17-144.

62. Roede, J.R.; Fritz, K.S. Hepatotoxicity of Reactive Aldehydes. In Reference Module in Biomedical Sciences; Elsevier: Amsterdam, The Netherlands, 2015.

63. Ghanbari, F.; Sayyari, M. Controlled drought stress affects the chilling-hardening capacity of tomato seedlings as indicated by changes in phenol metabolisms, antioxidant enzymes activity, osmolytes concentration and abscisic acid accumulation. Sci. Hortic. 2018, 229, 167-174. [CrossRef]

64. Ali, S.; Akbar Anjum, M.; Sattar Khan, A.; Nawaz, A.; Ejaz, S.; Khaliq, G.; Iqbal, S.; Ullah, S.; Naveed Ur Rehman, R.; Moaaz Ali, M.; et al. Carboxymethyl cellulose coating delays ripening of harvested mango fruits by regulating softening enzymes activities. Food Chem. 2021, 380, 131804. [CrossRef]

65. Tang, J.; Wang, S.Q.; Hu, K.D.; Huang, Z.Q.; Li, Y.H.; Han, Z.; Chen, X.Y.; Hu, L.Y.; Yao, G.F.; Zhang, H. Antioxidative capacity is highly associated with the storage property of tuberous roots in different sweetpotato cultivars. Sci. Rep. 2019, 9, 11141. [CrossRef]

66. Qin, S.; Liu, H.; Nie, Z.; Gao, W.; Li, C.; Lin, Y.; Zhao, P. AsA-GSH Cycle and Antioxidant Enzymes Play Important Roles in Cd Tolerance of Wheat. Bull. Environ. Contam. Toxicol. 2018, 101, 684-690. [CrossRef] [PubMed]

67. Mostofa, M.G.; Yoshida, N.; Fujita, M. Spermidine pretreatment enhances heat tolerance in rice seedlings through modulating antioxidative and glyoxalase systems. Plant Growth Regul. 2014, 73, 31-44. [CrossRef]

68. Hernández, J.A.; Barba-Espín, G.; Diaz-Vivancos, P. Glutathione-Mediated Biotic Stress Tolerance in Plants. In Glutathione in Plant Growth, Development, and Stress Tolerance; Springer International Publishing: New York, NY, USA, 2017; pp. $309-329$.

69. Begara-Morales, J.C.; Sánchez-Calvo, B.; Chaki, M.; Valderrama, R.; Mata-Pérez, C.; Padilla, M.N.; Corpas, F.J.; Barroso, J.B. Antioxidant Systems are Regulated by Nitric Oxide-Mediated Post-translational Modifications (NO-PTMs). Front. Plant Sci. 2016, 7, 152. [CrossRef] 
70. Hasanuzzaman, M.; Bhuyan, M.H.M.B.; Anee, T.I.; Parvin, K.; Nahar, K.; Mahmud, J.A.; Fujita, M. Regulation of AscorbateGlutathione Pathway in Mitigating Oxidative Damage in Plants under Abiotic Stress. Antioxidants 2019, 8, 384. [CrossRef] [PubMed]

71. Hasanuzzaman, M.; Bhuyan, M.H.M.; Zulfiqar, F.; Raza, A.; Mohsin, S.; Mahmud, J.; Fujita, M.; Fotopoulos, V. Reactive Oxygen Species and Antioxidant Defense in Plants under Abiotic Stress: Revisiting the Crucial Role of a Universal Defense Regulator. Antioxidants 2020, 9, 681. [CrossRef]

72. Hao, S.; Cao, H.; Wang, H.; Pan, X. The physiological responses of tomato to water stress and re-water in different growth periods. Sci. Hortic. 2019, 249, 143-154. [CrossRef]

73. Elmardy, N.A.; Yousef, A.F.; Lin, K.; Zhang, X.; Ali, M.M.; Lamlom, S.F.; Kalaji, H.M.; Kowalczyk, K.; Xu, Y. Photosynthetic performance of rocket (Eruca sativa. Mill.) grown under different regimes of light intensity, quality, and photoperiod. PLoS ONE 2021, 16, e0257745. [CrossRef] [PubMed]

74. Youssef, M.A.; Yousef, A.F.; Ali, M.M.; Ahmed, A.I.; Lamlom, S.F.; Strobel, W.R.; Kalaji, H.M. Exogenously applied nitrogenous fertilizers and effective microorganisms improve plant growth of stevia (Stevia rebaudiana Bertoni) and soil fertility. AMB Express 2021, 11, 133. [CrossRef]

75. Liang, D.; Yousef, A.F.; Wei, X.; Ali, M.M.; Yu, W.; Yang, L.; Oelmüller, R.; Chen, F. Increasing the performance of Passion fruit (Passiflora edulis) seedlings by LED light regimes. Sci. Rep. 2021, 11, 20967. [CrossRef]

76. Wu, X.; Sun, T.; Xu, W.; Sun, Y.; Wang, B.; Wang, Y.; Li, Y.; Wang, J.; Wu, X.; Lu, Z.; et al. Unraveling the Genetic Architecture of Two Complex, Stomata-Related Drought-Responsive Traits by High-Throughput Physiological Phenotyping and GWAS in Cowpea (Vigna. Unguiculata L. Walp). Front. Genet. 2021, 12, 743758. [CrossRef]

77. Filipović, A. Water Plant and Soil Relation under Stress Situations. In Soil Moisture Importance; IntechOpen: London, UK, 2021.

78. Chen, J.; Wang, Q.; Li, M.; Liu, F.; Li, W. Does the different photosynthetic pathway of plants affect soil respiration in a subtropical wetland? Ecol. Evol. 2016, 6, 8010-8017. [CrossRef] [PubMed]

79. Xiao, M.; Li, Y.; Lu, B.; Miao, Z. Response of Physiological Indicators to Environmental Factors under Water Level Regulation of Paddy Fields in Southern China. Water 2018, 10, 1772. [CrossRef]

80. Kaushal, R.; Singh, I.; Thapliyal, S.D.; Gupta, A.K.; Mandal, D.; Tomar, J.M.S.; Kumar, A.; Alam, N.M.; Kadam, D.; Singh, D.V.; et al. Rooting behaviour and soil properties in different bamboo species of Western Himalayan Foothills, India. Sci. Rep. 2020, 10, 4966. [CrossRef]

81. Pandey, V.; Swami, R.K.; Narula, A. Harnessing the Potential of Roots of Traditional Power Plant: Ocimum. Front. Plant Sci. 2021, 12, 2387. [CrossRef]

82. Qi, W.; Zhang, J.W.; Wang, K.J.; Liu, P.; Dong, S.T. Effects of drought stress on the grain yield and root physiological traits of maize varieties with different drought tolerance. Ying Yong Sheng Tai Xue Bao 2010, 21, 48-52. [PubMed]

83. Ullah, H.; Gul, B.; Khan, H.; Zeb, U. Effect of salt stress on proximate composition of duckweed (Lemna minor L.). Heliyon 2021, 7, e07399. [CrossRef] [PubMed] 